\title{
Retraction: Association of body weight and physical activity with blood pressure in a rural population in the Dikgale village of Limpopo Province in South Africa
}

\author{
Seth S Mkhonto ${ }^{1,2^{*}}$, Demetre Labadarios ${ }^{1}$ and Musawenkosi LH Mabaso ${ }^{3}$
}

This article [1] has been retracted by the Editor because the authors do not have ownership of the data they report. A formal investigation conducted by the University of Limpopo, South Africa, has concluded that the data reported in this article are the sole property of the University of Limpopo.

\begin{abstract}
Author details
${ }^{1}$ Population Health, Health Systems and Innovation, Human Sciences Research Council, 134 Pretorius Street, Pretoria 0002, South Africa.

${ }^{2}$ Department of Medical Science, University of the Limpopo, Turfloop Campus, Fauna Park, Polokwane, 0787, South Africa. ${ }^{3}$ HIV/AIDS, STIs and TB, Human Sciences Research Council, 750 Francois Road, Durban 4001, South Africa.
\end{abstract}

Received: 2 September 2013 Accepted: 2 September 2013

Published: 18 October 2013

\section{Reference}

1. Mkhonto SS, Labadarios D, Mabaso MLH: Association of body weight and physical activity with blood pressure in a rural population in the Dikgale village of Limpopo Province in South Africa. BMC Res Notes 2012, 5:118.

\section{doi:10.1186/1756-0500-6-422}

Cite this article as: Mkhonto et al:: Retraction: Association of body weight and physical activity with blood pressure in a rural population in the Dikgale village of Limpopo Province in South Africa. BMC Research Notes 2013 6:422

\footnotetext{
* Correspondence: smkhonto@hsrc.ac.za

${ }^{1}$ Population Health, Health Systems and Innovation, Human Sciences Research Council, 134 Pretorius Street, Pretoria 0002, South Africa ${ }^{2}$ Department of Medical Science, University of the Limpopo, Turfloop Campus, Fauna Park, Polokwane, 0787, South Africa

Full list of author information is available at the end of the article
}

Submit your next manuscript to BioMed Central and take full advantage of:

- Convenient online submission

- Thorough peer review

- No space constraints or color figure charges

- Immediate publication on acceptance

- Inclusion in PubMed, CAS, Scopus and Google Scholar

- Research which is freely available for redistribution

Submit your manuscript at www.biomedcentral.com/submit 